Article

\title{
Anti-Biofouling and Desalination Properties of Thin Film Composite Reverse Osmosis Membranes Modified with Copper and Iron Nanoparticles
}

\author{
M. Armendariz Ontiveros ${ }^{1}$, Y. Quintero ${ }^{2}{ }^{(D}$, A. Llanquilef $^{2}$, M. Morel $^{3}{ }^{(0)}$, \\ L. Argentel Martínez ${ }^{1,4}$, A. García García ${ }^{5}$ and A. Garcia ${ }^{2, *}$ \\ 1 Instituto Tecnológico de Sonora. 5 de Febrero 818 Sur, Sonora 85000, Mexico \\ 2 Advanced Mining Technology Center (AMTC), Universidad de Chile, Santiago 8370451, Chile \\ 3 Facultad de Ciencias Naturales, Departamento de Química y Biología, Universidad de Atacama, \\ Copiapó 1531772, Chile \\ 4 Instituto Tecnológico del Valle del Yaqui, C. 600, Block 611, Sonora 85275, Mexico \\ 5 Laboratorio de Síntesis y Modificación de Nanoestructuras y Materiales Bidimensionales, \\ Centro de Investigación en Materiales Avanzados S.C. Parque PIIT, Apodaca Nuevo León 66628, Mexico \\ * Correspondence: andreina.garcia@amtc.cl; Tel.: +56-2-29771015
}

Received: 4 June 2019; Accepted: 26 June 2019; Published: 28 June 2019

\begin{abstract}
The anti-biofouling and desalination properties of thin film composite reverse osmosis membranes (TFC-RO), modified by the incorporation of copper and iron nanoparticles, were compared. Nanoparticles of metallic copper (CuNPs) and an iron crystalline phase mix (Fe and $\mathrm{Fe}_{2} \mathrm{O}_{3}$, FeNPs) were obtained by oxide-reduction-precipitation and reduction reactions, respectively, and characterized by $\mathrm{X}$-ray diffraction (XRD) and transmission electron microscopy (TEM) techniques. Modified membranes (PA+0.25Cu-PSL and PA+0.25Fe-PSL) were obtained by incorporating these nanoparticles during the interfacial polymerization process (PI). These membranes were characterized by scanning electron microscopy (SEM), energy-dispersive X-ray spectroscopy (EDX), atomic force microscopy (AFM), and contact angle measurements. Bactericidal tests by a Colony Forming Unit (CFU) were performed using Escherichia coli, and anti-adhesion properties were confirmed by fluorescence microscopy estimating the percentage of live/dead cells. The permeate flow and rejection of salts was evaluated using a crossflow cell. An increase of the membrane's roughness on the modified membrane was observed, influencing the desalination performance more strongly in the presence of the FeNPs with respect to the CuNPs. Moreover, a significant bactericidal and anti-adhesion effect was obtained in presence of both modifications with respect to the pristine membrane. An important decrease in CFU in the presence of modified membranes of around $98 \%$ in both modifications was observed. However, the anti-adhesion percentage and reduction of live/dead cells were higher in the presence of the copper-modified membrane in comparison to the iron-modified membrane. These facts were attributed to the differences in antimicrobial action mechanism of these types of nanoparticles. In conclusion, TFC-RO membranes modified by the incorporation of CuNPs during PI represent one alternative material to attend to the biofouling impact in the desalination process.
\end{abstract}

Keywords: biofouling; $\mathrm{RO}$ membranes; $\mathrm{Cu}$ nanoparticles; Fe nanoparticles; desalination

\section{Introduction}

Reverse osmosis (RO) desalination is a possible alternative that reduces water scarcity rates worldwide [1]. RO had an annual contracted capacity of 2.2 million $\mathrm{m}^{3} \mathrm{~d}^{-1}$ in 2017 [2]. The main RO membranes on the market are based on a polyamide (PA) thin film composite (TFC) synthesized by an 
interfacial polymerization process, which consists of a combination of an aqueous m-phenylenediamine (MPD) solution and an organic trimesoyl chloride (TMC) solution [3]. However, TFC-RO membranes face a biofouling problem, which involves the adhesion, growth, reproduction, and proliferation of microorganisms onto the membrane surface [4], causing permeate flux reduction, increasing the operating pressure, and therefore increasing process costs [5].

In order to avoid biofouling in the membranes, researchers have incorporated, on the PA layer, different inorganic nanoparticles (NPs) with antimicrobial properties, such as $\mathrm{Ag}, \mathrm{TiO}_{2}$, and $\mathrm{ZnO}$, among others [6-8]. However, some of these NPs are quite expensive because of the extraction process from the earth and are difficult to synthesize. For this reason, it is necessary to use antimicrobial NPs that are easy to obtain from nature, easy to synthesize, and are easily added to TFC membranes without significant costs to the desalination process, such as copper and iron nanoparticles [9-11].

These two types of NPs have a high biocide effect against a large diversity of microorganisms by different mechanisms. Since iron nanoparticles reduce nutrient transport into bacteria cells, they cause nutritional imbalances and metabolic weakness in bacteria. In addition, they produce oxidative stress by generation of some reactive oxygen species (ROS) with free radicals (Fenton or Fenton-like reaction), damaging cellular proteins, lipids, and DNA, and eventually leading to bacteria death [12,13]. On the other hand, the copper nanoparticles act by releasing ions, thereby destroying vital parts of the bacteria cells. In addition, they also generate ROSs that damage the bacteria's DNA, killing them [14].

Despite this, it is important to note that the bactericidal effect of copper and iron can be influenced by the type nanoparticles, either metallic or oxide. In the case of iron nanoparticles, although both types possess antimicrobial properties, metallic nanoparticles are more bactericidal than iron oxides. In the presence of dissolved oxygen, metallic iron nanoparticles can generate a Fenton reaction, producing hydrogen peroxide in addition to ROS [15].

Likewise, differences in the biocidal effect between metallic and oxide copper nanoparticles can also be observed. The biocidal mechanism of copper oxide nanoparticles has been associated with ion release, since these are highly soluble [16]. Moreover, the redox cycle, caused between the ionic species $\mathrm{Cu}$ (I) and $\mathrm{Cu}$ (II), generates reactive superoxide species that contribute to the degradation of biomolecules [17]. However, metallic copper nanoparticles could have a greater biocidal effect considering that, in addition to the release of copper ions, the mechanism for the biocidal effect also corresponds to the generation of greater reactive oxygen species (ROSs). The absorption of this nanoparticle by microorganisms leads to a series of interactions at the level of structural proteins, organelles, and DNA, contributing to oxidative stress within the cell $[18,19]$.

Thus, the modification of $\mathrm{RO}$ membranes with metallic or oxide nanoparticles in order to improve the anti-biofouling effect is not a trivial issue. Metallic nanoparticles could favor the effect with respect to the oxidized species.

In this regard, some proposals about TFC membranes modified with copper and iron nanoparticles have been reported in recent years [20-24]. For this, development of several strategies to modify TFC $\mathrm{RO}$ membranes with these nanoparticles have been proposed; these strategies include the dip-coating method, which is one alternative that was widely reported [12,21-23].

For example, Ben-Sasson et al. [21] functionalized a TFC RO membrane with elemental $\mathrm{Cu}$ nanoparticles (CuNPs) by using a dipping method and obtained a $80 \%-95 \%$ reduction in the bacteria adhesion onto the membrane surface. Moreover, Ben-Sasson et al. [22] also coated a commercial TFC RO membrane with in situ formed CuNPs and obtained a flux increment $(20 \%)$ and a reduction in bacterial attachment onto the membrane surface (90\%). Nevertheless, these modification methods have shown low stability as their principal disadvantage.

In this regard, modifications during the interfacial polymerization process represent another alternative. For example, Garcia et al. [20] incorporated CuONPs onto the PA layer of a TFC membrane during the interfacial polymerization process and obtained a high anti-adhesion and bactericidal effect, without affecting the membrane performance. In addition, Rodriguez et al [24], added in situ, during the interfacial polymerization process, a $\mathrm{Cu}$-(m-phenylenediamine) oligomer complex within the PA 
layer of the TFC-RO membrane. They found a $99 \%$ bacterial reduction onto membranes and obtained an increment of $25 \%$ in permeate flux.

Thus, although the incorporation of different types of copper nanoparticles ( $\mathrm{CuO}$ and oligomers) during the interfacial polymerization process into the PA layer have been explored, the use of metallic copper nanoparticles (CuNPs) during this process has not been studied yet. Therefore, significant differences in anti-biofouling effects could be observed in the presence of $\mathrm{Cu}$ nanoparticles with respect to others (such as $\mathrm{CuO}$ nanoparticles), considering the differences in the bactericidal mechanism of these types of nanoparticles. Thus, the incorporation of metallic copper nanoparticles (CuNPs) could have favorable performance with respect to the options explored at the moment.

On the other hand, TFC membranes modified with iron nanoparticles have been infrequently studied. For example, Armendariz et al. [12] modified a commercial membrane surface with FeNPs by using a dip coating method, obtaining a reduction of $90 \%$ in the formation of a biofilm cake layer, but affecting the desalination performance membrane. In this case, the modification method was dip coating, which has disadvantages due to the low stability described above.

Meanwhile, only one approach to modify with iron nanoparticles during the interfacial polymerization process was done by Homayoonfal et al. [25], who incorporated iron oxide nanoparticles $\left(\mathrm{Fe}_{3} \mathrm{O}_{4} \mathrm{NPs}\right)$ into the PA layer membrane, observing an enhance in the membrane flux. Nevertheless, in this case, the anti-biofouling effect was not studied.

In this way, the incorporation of nanoparticles in the PA layer membranes during the interfacial polymerization process is an alternative method of modifying $\mathrm{RO}$ membranes. However, the incorporation of metallic copper (CuNPs) and iron (FeNPs) nanoparticles into the PA layer during this interfacial polymerization process has not been studied yet.

Thus, considering that both nanoparticles have significant antimicrobial properties, but differences in the antimicrobial action mechanism have been reported between them, their incorporation into TFC-RO membranes could be an interesting comparative study on their influence on anti-biofouling effects and the desalination performance of these modified membranes. Therefore, this research aims are to modify $\mathrm{RO}$ membranes by incorporating metallic $\mathrm{Cu}$ and $\mathrm{Fe}$ nanoparticles into the PA layer during the interfacial polymerization process in order to enhance anti-biofouling and anti-adhesion properties and study their behavior in the desalination performance.

\section{Materials and Methods}

The following chemicals were used: ferric nitrate $\left(\mathrm{Fe}\left(\mathrm{NO}_{3}\right)_{3} \cdot 9 \mathrm{H}_{2} \mathrm{O} ;>99 \%\right.$, ACS, Fermont, Monterrey, Mexico), ethanol $\left(\mathrm{C}_{2} \mathrm{H}_{5} \mathrm{OH} ;>99 \%\right.$, J.T. Baker, Mexico), sodium borohydride $\left(\mathrm{NaBH}_{4}\right.$; $>99 \%$, Fluka, Mexico city, Mexico) used for FeNP synthesis. L-ascorbic acid $\left(\mathrm{C}_{6} \mathrm{H}_{8} \mathrm{O}_{6} ;>99 \%\right.$, Sigma Aldrich, Darmstadt, Germany), copper sulphate $\left(\mathrm{CuSO}_{4} \cdot 5 \mathrm{H}_{2} \mathrm{O} ;>99 \%\right.$, ACS, Fermont, Monterrey, Mexico), etilenglicol $\left(\mathrm{C}_{2} \mathrm{H}_{6} \mathrm{O}_{2} ;>99.5 \%\right.$, Merck, Nottingham, UK), sodium hydroxide $(\mathrm{NaOH} ;>50 \%$ p/v, Winkler, Santiago, Chile) used for CuNP synthesis. Polysulfone Udel P-3500 MB7 (in pellet form, Solvay Advanced Polymers), 1-methyl-2 pyrrolidinone (NMP, > 99.5\%, Sigma Aldrich, Darmstadt, Germany), and N,Ndimethylformamide (DMF, > 99\%, Sigma Aldrich, Darmstadt, Germany) were used to make the polysulfone (PSL) sheet used as membrane support. $m$-phenylenediamine (MPD) and trimesoyl chloride (TMC) (Sigma Aldrich, Darmstadt, Germany), NaOH (> 97\%, Sigma Aldrich, Darmstadt, Germany), and $n$-hexane (> 95\%, Sigma Aldrich, Darmstadt, Germany) were used for PA monomer synthesis.

\subsection{Synthesis of $\mathrm{CuNPs}$ and FeNPs}

CuNPs were obtained following Liu et al. [26] by an oxide-reduction-precipitation reaction. The type of stirring and wash processes were modified. Into a solution of $\mathrm{CuSO}_{4} \cdot 5 \mathrm{H}_{2} \mathrm{O}$ in ethylene glycol $\left(40 \mathrm{~g} \mathrm{~L}^{-1}\right), 17 \mathrm{~g}$ of ascorbic acid and $250 \mathrm{~mL}$ of Sodium hydroxide were added to $0.01 \mathrm{M}$; this solution was maintained under sonication to $55^{\circ} \mathrm{C}$ and at $53 \mathrm{KHz}$ for $1 \mathrm{~h}$. Once the reaction was complete, a red precipitate was obtained and separated from the supernatant. The reddish solid was 
washed with a $2 \%$ solution of MPD and dried in a vacuum oven (Thermo Fisher Scientific, Madrid, Spain) for $8 \mathrm{~h}$ at $60^{\circ} \mathrm{C}$.

FeNPs were synthetized following Baltazar et al. [27] and Arancibia-Miranda et al. [28,29]. $\mathrm{NaBH}_{4}$ aqueous solution $\left(4.48 \mathrm{~g} \mathrm{~L}^{-1}\right)$ was added to a $\mathrm{Fe}\left(\mathrm{NO}_{3}\right)_{3} \cdot 9 \mathrm{H}_{2} \mathrm{O}$ aqueous solution $\left(4.00 \mathrm{~g} \mathrm{~L}^{-1}\right)$ and kept under agitation for $1 \mathrm{~h}$ at $25^{\circ} \mathrm{C}$. After this time, the nanoparticles were washed with distilled water and acetone.

\subsection{Characterization of $\mathrm{CuNPs}$ and FeNPs}

X-ray Diffraction (XRD) analysis was performed in order to study the crystallinity of the CuNPs and FeNPs. The XRD tests were done in a diffractometer (Bruker D8 Advance) (Bruker, Madison, USA) with $\mathrm{CuK} \alpha$ radiation. Transmission electron microscopy (TEM) was used to observe the morphology and size of the CuNPs and FeNPs. TEM micrographs were taken in a microscope (Tecnai F20 FEG-S/TEM) (FEI Tecnai, Texas, USA) operated at $200 \mathrm{kV}$. The particle size distribution was obtained by processing TEM images with the DigitalMicrograph software (Gatan, Pleasanton, USA) for a population of at least 100 particles.

\subsection{Synthesis of TFC RO Membrane with CuNPs and FeNPs}

TFC membranes modified by incorporating CuNPs and FeNPs were prepared following the method of Garcia et al. $[6,20]$. A polysulfone (PSL) solution was prepared by dissolving polysulfone pellets $(16 \mathrm{wt} \%)$ in a 4:1 DMF/NMP mixture, stirred for $2 \mathrm{~h}$ at $50{ }^{\circ} \mathrm{C}$. The PSL membrane support was prepared by spreading the polymer solution uniformly on a glass plate using a film-casting knife (BYK, Geretsried, Germany) with a clearance set at $200 \mu \mathrm{m}$. Then, the membrane support was submerged in a coagulation bath after $1 \mathrm{~min}$ and washed exhaustively with distilled water in order to get rid of any residual solvent under laboratory conditions.

PA and modified PA with CuNPs and FeNPs were prepared using the interfacial polymerization reaction of the aqueous phase of the MPD and the organic phase of the TMC on the porous PSL substrate. The PSL support was placed for $2 \mathrm{~min}$ in a $2 \mathrm{wt} \%$ aqueous MPD solution containing $0.05 \mathrm{wt} \%$ $\mathrm{NaOH}$. Next, the support was immersed in a $0.2 \mathrm{wt} \%$ TMC solution in hexane for $1 \mathrm{~min}$ to allow interfacial polymerization. Then, the membrane was cured in an air circulation oven (Thermo Fisher Scientific, Madrid, Spain) at $75^{\circ} \mathrm{C}$ for $8 \mathrm{~min}$. After, it was washed with distilled water and dried at room temperature for $24 \mathrm{~h}$. The modified membrane was prepared by adding CuNPs $(0.25 \mathrm{wt} \%)$ and FeNPs $(0.25 \mathrm{wt} \%)$ homogeneously dispersed in an MPD solution with an ultrasonic bath to prepare the CuNPs and FeNP-entrapping PA layers on the porous PSL supports, referred to as PA+0.25Cu-PSL and PA+0.25Fe-PSL, respectively.

\subsection{Characterization of Membranes Modified by Incorporation of CuNPs and FeNPs}

The surface morphology of the membranes and their elemental analysis were examined by SEM-EDX-CL (FEI Quanta 250) (Thermo Fisher Scientific, Madrid, Spain). The SEM measurements were performed at low vacuum conditions with a Helix detector (Thermo Fisher Scientific, Madrid, Spain) at $5 \mathrm{kV}$. The samples were deposited on a lacey form over carbon, with 300 mesh Cu grids, prior to examination. Changes in the surface roughness of the membranes were examined by AFM (NanoWizard 3 BioScience, JPK Instruments) (Bruker, Madison, USA). Hydrophilicity analysis was realized by the contact angle measured by placing a drop of ultra-pure water on the surface membrane and performing a drop-shape analysis. Contact angle images were captured using a Digi-Microscope camera (JENOPTIK, Fremont, USA), a zoom lens of 500X, and a resolution of $11 \mu \mathrm{m} /$ pixel.

\subsection{Anti-Biofouling Test}

Escherichia coli (E. coli) was used to evaluate the bactericidal effect of membranes, following the methodologies of Garcia et al. [6,20] and Rodriguez et al. [24]. Bacteria were inoculated in a solution (tryptone soya broth, TSB) and incubated in a shaking incubator at $30^{\circ} \mathrm{C}$. Then, the bacterial 
solution was centrifuged to remove nutrients at $3000 \mathrm{rpm}$ for $10 \mathrm{~min}$ and washed in phosphate-buffered saline (PBS). The prepared bacteria were diluted in PBS to obtain a bacteria concentration of about $1 \times 10^{7} \mathrm{cell} / \mathrm{mL}$. The membrane samples were cut $\left(2 \times 2 \mathrm{~cm}^{2}\right)$ and sterilized using ultraviolet radiation for $30 \mathrm{~min}$. Then, membranes were immersed into $10 \mathrm{~mL}$ of the bacterial solution and incubated in the shaking incubator at $30^{\circ} \mathrm{C}$ for $4 \mathrm{~h}$. After this time, and to learn the bactericidal effect of the modified membranes in the medium, the bacterial solutions were serially diluted with PBS until achieving a concentration of $1 \times 10^{-3}$ cell $/ \mathrm{mL}$. Later, $1 \mathrm{~mL}$ of the dilutions was spread, by triplicate, onto the surface of petri-dishes containing LB agar, and incubated for 24 hours, at $35^{\circ} \mathrm{C}$. Then, the colonies were counted to estimate the number of viable E. coli remaining in the suspensions.

The bacterial adhesion onto membranes was assessed by the live and dead method. After being incubated for $4 \mathrm{~h}$, the membranes were removed from the suspension and gently rinsed with a $0.85 \mathrm{wt} \% \mathrm{NaCl}$ solution in water to remove the unadhered bacteria. Membranes were cut $\left(1 \mathrm{~cm}^{2}\right)$ in order to evaluate bacterial viability using a bacterial viability kit (Molecular Probes, LIVE/DEAD BacLight L7007) (Thermo Fisher Scientific, Madrid, Spain). Results were analyzed by epifluorescence microscope (Zeiss, AxioLab A1, Zeiss, Darmstadt, Germany) with a 100X objective. Live and dead cells were counted, and the results were statistically processed in order to estimate the bactericidal and anti-adhesion effects on the membrane surface.

\subsection{Statistical Analysis}

For the colony forming units (CFU), live and dead cells, the theoretical t-student probability distribution of $\mathrm{p} \leq 0.001$ was used, using a sample size of $\mathrm{n}<30$. For all analyses, the professional statistical software STATISTIC 8.5 (OriginLab, Northampton, USA) was used.

\subsection{Desalination Performance Test}

Permeate flux and salt rejection of the membranes were evaluated using a cross flow test cell, a feed solution of $1000 \mathrm{mg} / \mathrm{L} \mathrm{NaCl}$ at $300 \mathrm{psi}$, and an effective membrane area of $33 \mathrm{~cm}^{2}$, following the previous report $[20,24]$. The experiments were carried out at a temperature of $25 \pm 1{ }^{\circ} \mathrm{C}$. During $60 \mathrm{~min}$, the permeate flux test of the membranes was calculated and the solute rejection was measured from the feed and the permeate solution concentrations. The conductivity of these two solutions was measured to obtain their respective concentration values.

\section{Results and Discussions}

\subsection{Characterization of $\mathrm{Cu}$ and Fe Nanoparticles}

The XRD results of the CuNPs and FeNPs synthesized are shown in Figure 1. Figure 1a shows a copper compound, where the crystalline system of CuNPs is cubic. Characteristic picks appear at $2 \theta=43.3^{\circ}, 50.4^{\circ}$ and $74.1^{\circ}$, corresponding to metallic $\mathrm{Cu}[20,30,31]$. In addition, the spectrum shows peaks at $2 \theta=36.44^{\circ}$ and $61.41^{\circ}$, corresponding to $\mathrm{Cu}_{2} \mathrm{O}[22,32]$ in low concentrations. This result may be attributed to the easy oxidation of CuNPs in the atmosphere $[23,24,33,34]$.

On the other hand, in Figure $1 \mathrm{~b}$ it is possible to observe the presence of iron mix compounds, where the distinctive points of Fe appear at $2 \theta=44.5^{\circ}$ and $65.0^{\circ}$, confirming the crystalline structure of the FeNPs [14,30]. In addition, another phase corresponding to iron oxide (III) $\left(\mathrm{Fe}_{2} \mathrm{O}_{3}\right)$ was found with peaks at $2 \theta=30.3^{\circ} ; 35.6^{\circ} ; 43.5^{\circ} ; 57.2^{\circ}$, and $62.7^{\circ}$ [29]. The $\mathrm{Fe}_{2} \mathrm{O}_{3}$ presences is probably due to the easy oxidation of FeNPs in air [32]. 


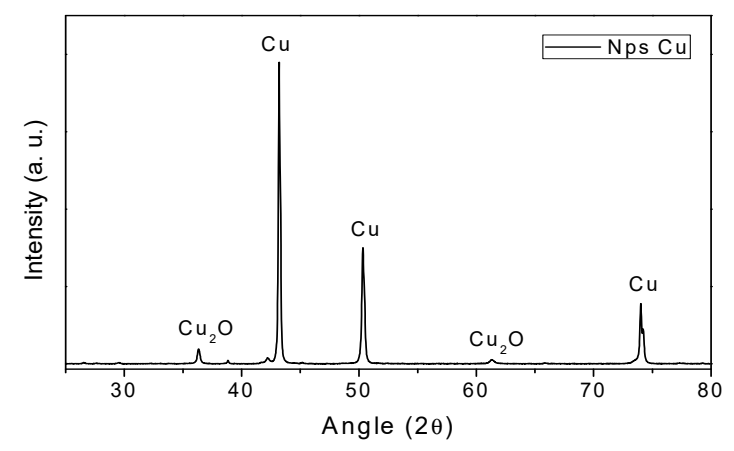

(a)

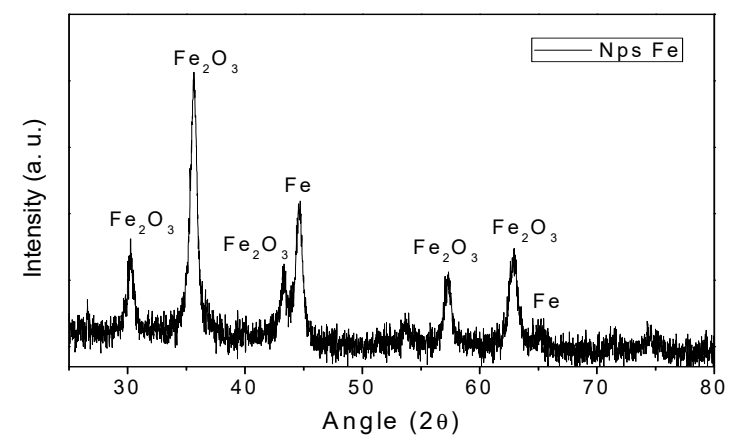

(b)

Figure 1. XRD patterns of the samples. (a) CuNPs; (b) FeNPs.

In Figure 2, TEM images and particle size distributions of the nanoparticles are shown. The TEM image of Figure 2a exhibits the formation of nanoparticles of CuNPs embedded in the stabilized agent used in the washing process. The particle size distribution of CuNPs shows two populations between 3-8 $\mathrm{nm}$ and 13-27 $\mathrm{nm}$, with the mean particle size around $13.5 \pm 8.0 \mathrm{~nm}$. In Figure $2 \mathrm{~b}$, it is possible to observe spherical shapes for FeNPs with mean particle size distributions around $14.6 \pm 1.2 \mathrm{~nm}$. An amorphous matrix is observed around the nanoparticles related to the residual reductant agent used in the synthesis. It is showed that both CuNPs and FeNPs have similar particle sizes. Also, both NPs have a very small particle size $(<30 \mathrm{~nm})$, which could improve the NP dispersion into the PA layer by increasing the coverage area of the NPs into the membrane, causing higher contact with bacteria, which could increase the biocide effect of the membranes [35].
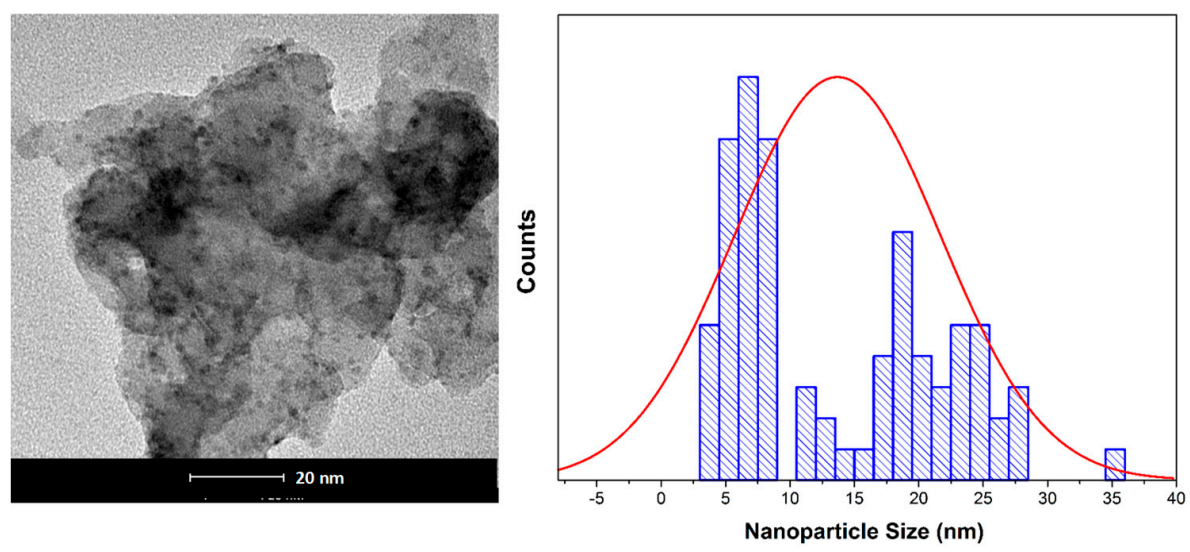

(a)

Figure 2. Cont. 

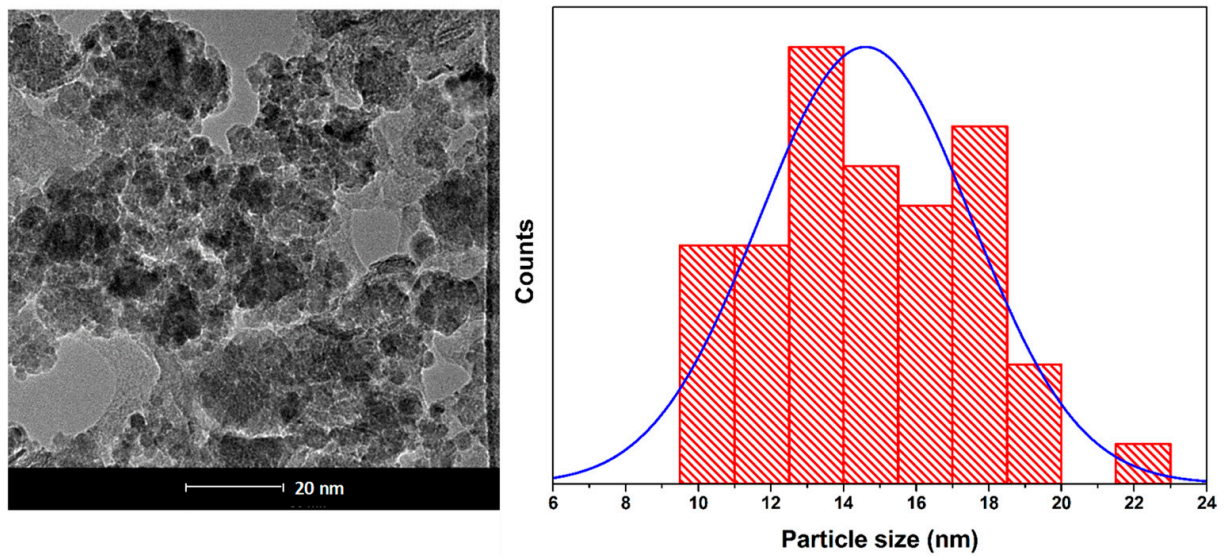

(b)

Figure 2. Transmission electron microscopy images and particle size distributions. (a) CuNPs; (b) FeNPs.

\subsection{Characterization of Modified and Unmodified TFC RO Membranes}

Figure 3 shows the SEM images of the PA-PSL, PA+0.25Cu-PSL, and PA+0.25Fe-PSL membrane surfaces (Figure $3 a, b$ and $c$, respectively). It exhibits the morphological surface of pristine membrane without nanoparticles (Figure 3a). Moreover, certain agglomeration of the nanoparticles on modified membranes can be observed (Figure $3 b$ and $c$ ).

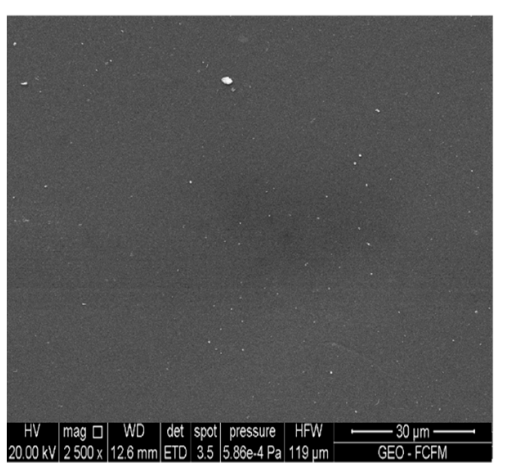

(a)

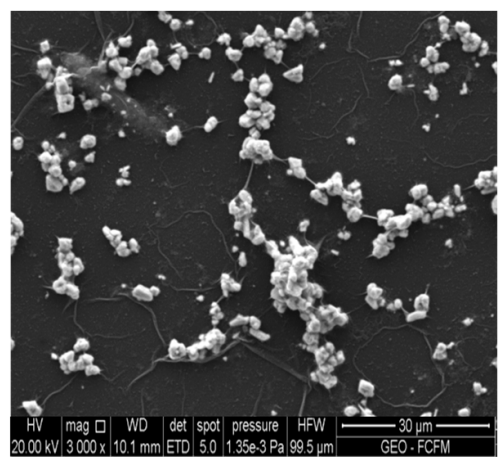

(b)

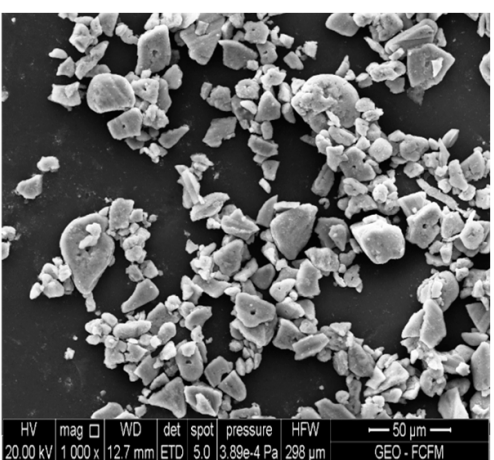

(c)

Figure 3. SEM images of the membrane surface (a) PA-PSL; (b) PA+0.25Cu-PSL; (c) PA+0.25Fe-PSL.

The EDX results of membranes surfaces are shown in Figure 4, confirming the presence of $\mathrm{Cu}$ (Figure $4 \mathrm{~b}$ ) and $\mathrm{Fe}$ (Figure $4 \mathrm{c}$ ) in the active layer of the PA+0.25Cu-PSL and PA+0.25Fe-PSL membrane. In the table (inside of Figure $4 \mathrm{a}-\mathrm{c}$ ), it is possible to observe quantitative results of the analyses, evidencing that $\mathrm{C}, \mathrm{O}$, and $\mathrm{Cu}$ were the main elements on the PA+0.25Cu-PSL membrane surface (Figure $4 \mathrm{~b}$ ) and $\mathrm{C}, \mathrm{O}$, and Fe were on the PA+0.25Fe-PSL membrane surface (Figure $4 \mathrm{c}$ ). 


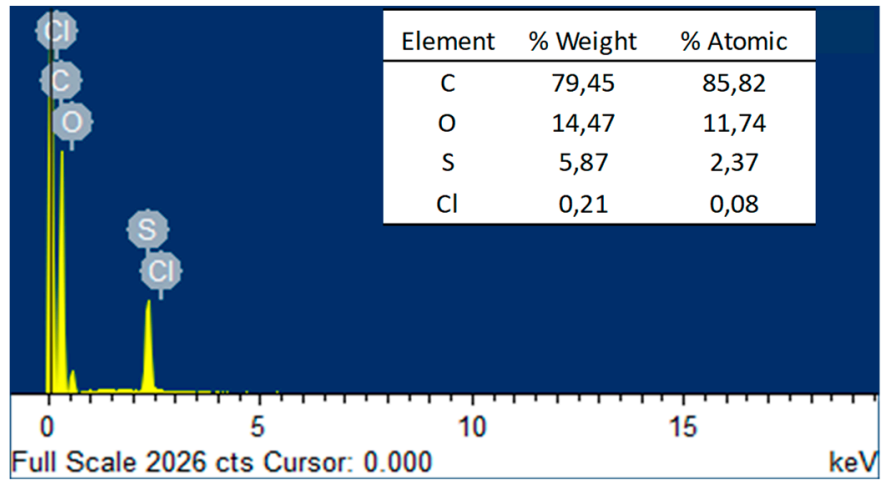

(a)

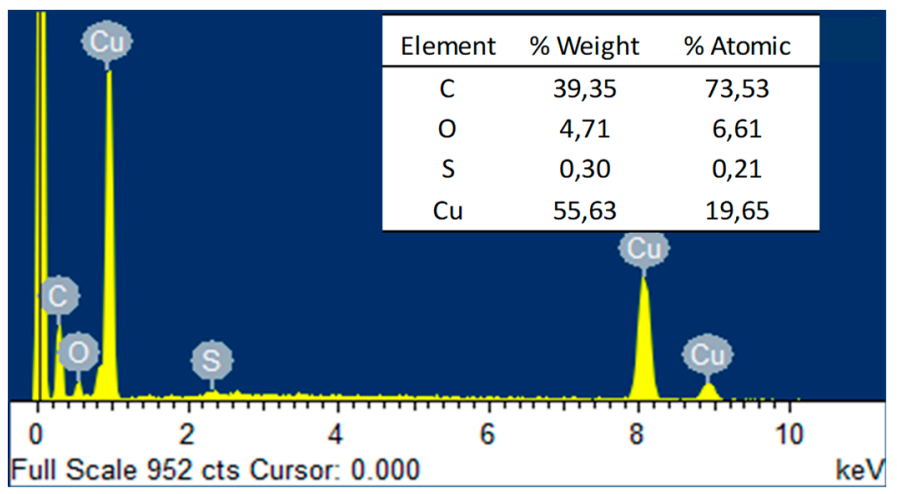

(b)

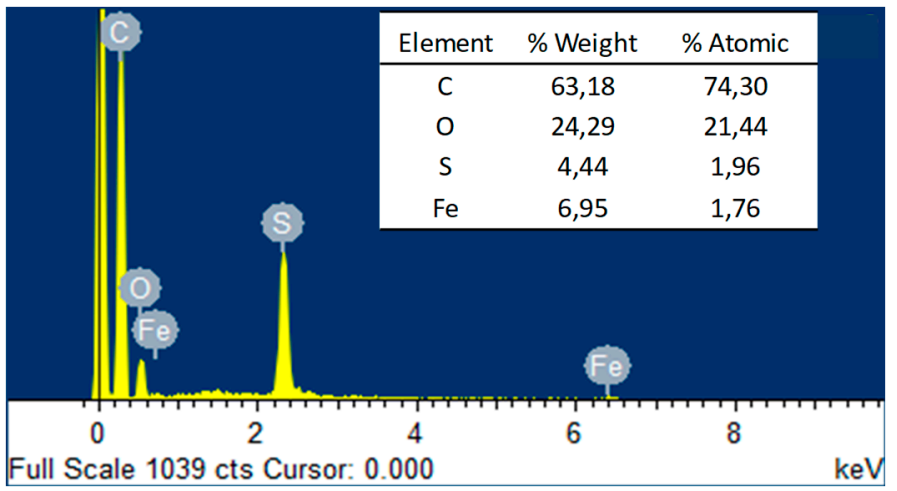

(c)

Figure 4. EDX analysis of membranes surface (a) PA-PSL; (b) PA+0.25Cu-PSL; (c) PA+0.25Fe-PSL.

Table 1 shows the roughness and contact angle values. In this table it is possible to observe significant changes in the roughness of modified membrane surfaces with respect to the pristine membrane. These values could be the result of the agglomeration tendency of NPs on the surface membranes in accordance with those observed in the SEM image (Figure 3). The PA+0.25Cu-PSL and PA+0.25Fe-PSL membranes' roughness showed highly significant differences, being rougher in the presence of FeNPs than CuNPs. It has been reported that iron nanoparticles have a high agglomeration tendency, which can be an impediment for their good uniform dispersion on the membrane surface [12,36]. This can be due to the high surface energy, magnetic force, and electrostatic interaction of these FeNPs, which could lead to cluster formation [12]. This result could increase bacterial adhesion onto the modified membranes, considering that microorganisms are prone to attach in rougher topologies, reducing the anti-biofouling effect $[6,20,24,37]$. 
Table 1. Surface properties of the membranes.

\begin{tabular}{lcc}
\hline \multicolumn{1}{c}{ Membrane } & Roughness $(\mathbf{n m})$ & Contact Angle $\left(^{\circ}\right)$ \\
\hline PA-PSL & $5.7 \pm 0.7$ & $74.25 \pm 6.47$ \\
PA+0.25Cu-PSL & $39.2 \pm 4.7$ & $99.42 \pm 6.13$ \\
PA+0.25Fe-PSL & $70.3 \pm 13.1$ & $74.21 \pm 1.55$ \\
\hline
\end{tabular}

On the other hand, contact angle results are also presented in Table 1 and visualized in Figure 5. No significant influences on this parameter in the presence of the PA+0.25Fe-PSL membrane with respect to unmodified membrane (PA-PSL) were observed. In this regard, the highest contact angle was found for the PA+0.25Cu-PSL membrane (> 33\% than PA-PSL). Thus, a significant decrease in the hydrophilicity character for the PA+0.25Cu-PSL membrane was observed [38], which is in concordance with previous reports for copper-modified membranes [20,24]. This fact suggests an alteration to the affinity of fouling materials for membrane surfaces [39] and a reduction of the solubility of water on the membrane surface.

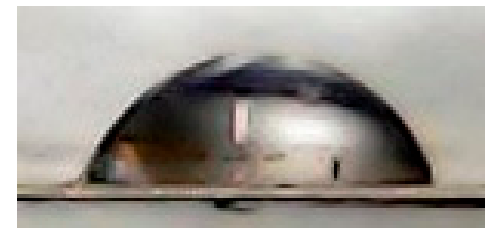

(a)

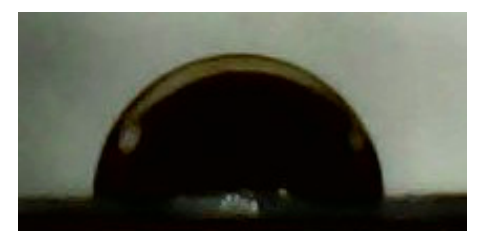

(b)

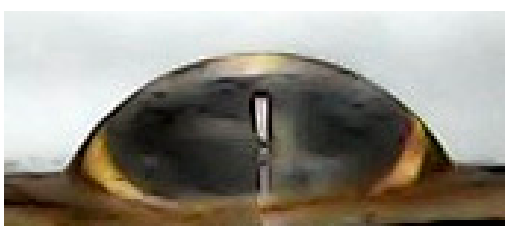

(c)

Figure 5. Images of water drops on membranes: (a) PA-PSL; (b) PA+0.25Cu-PSL; (c) PA+0.25Fe-PSL.

\subsection{Anti-Biofouling Effect}

Figure 6 shows the bactericidal effect of membranes in the medium, in which a highly significant decrease in CFU is observed in the presence of modified membranes with respect to the unmodified membrane. However, there was no statistically significant difference between both modified membranes. The reduction of the modified membranes with respect to the unmodified membrane was $>99 \%$ for PA $+0.25 \mathrm{Cu}-\mathrm{PSL}$ and $>98 \%$ PA+0.25Fe-PSL. This result evidences the great biocide effect of the CuNPs and FeNPs.

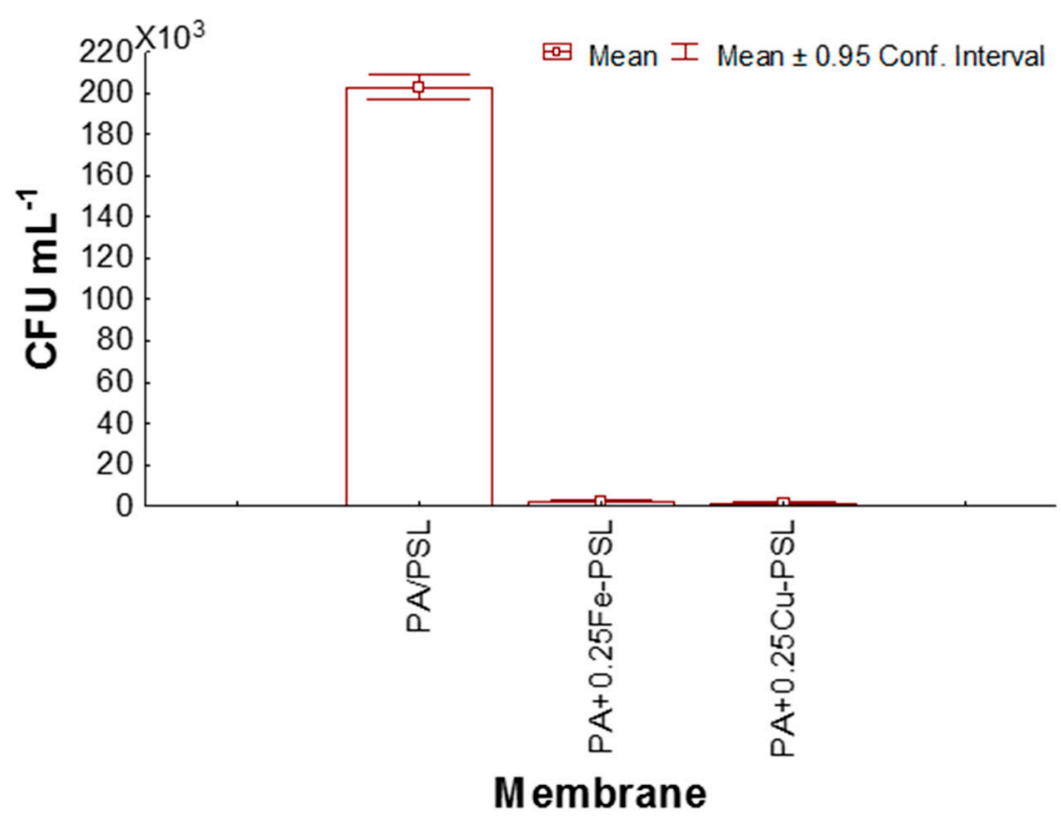

Figure 6. Bactericidal effect of the membranes on E. coli. 
On the other hand, the bacteria that adhered onto membranes are presented in Figure 7. It is possible to observe a highly significant reduction of the bacteria adhering onto the modified membranes with respect to the unmodified membrane. The total anti-adhesion percentage of PA+0.25Cu-PSL and PA+0.25Fe-PSL membranes were $97 \%$ and $83 \%$, respectively, demonstrating a better effect with modification via CuNPs. Moreover, a higher reduction of live cells on the membrane's surface was observed for PA+0.25Cu-PSL with respect to PA+0.25Fe-PSL.

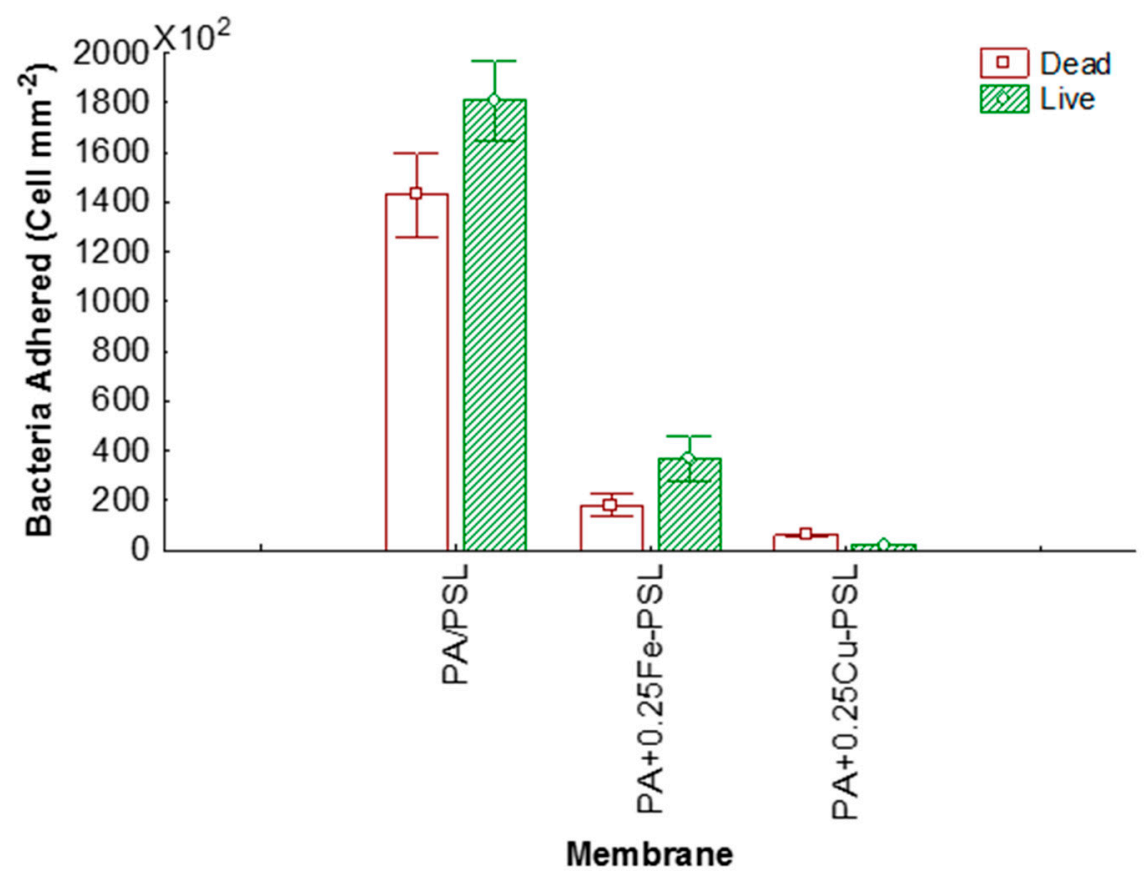

Figure 7. Cells of E. coli per area of the membranes.

These results may be attributed to the higher reactivity of CuNPs provided by the release of toxic $\mathrm{Cu}^{+2}$ ions, in addition to the generation of reactive oxygen species (ROS). CuNPs produce ROS in the medium that damages bacterial DNA causing bacterial death [14], and the release of ions increases intracellular ROS in the bacteria, thereby inflicting its death [40]. Meanwhile, the bactericidal power of FeNPs can be attributed only to ROS generation through the Fenton reaction, provoking bacterial death $[12,13,32,41]$. Previous reports have also described how CuNPs produce four ROS types [superoxide radical $\left(\mathrm{O}^{2-}\right)$, the hydroxyl radical $(\cdot \mathrm{OH})$, hydrogen peroxide $\left(\mathrm{H}_{2} \mathrm{O}_{2}\right)$, and singlet oxygen $\left(\mathrm{O}^{2}\right)$ ] [35] compared to only three ROS types $\left(\mathrm{O}^{2-}, \mathrm{OH}\right.$ and $\left.\mathrm{H}_{2} \mathrm{O}_{2}\right)$ produced by FeNPs [42], which can is associated with the best performance of the modified membranes with copper versus iron.

It must be also emphasized that the incorporated iron nanoparticle into the membrane was an iron crystalline phase mix $\left(\mathrm{Fe}\right.$ and $\left.\mathrm{Fe}_{2} \mathrm{O}_{3}\right)$. Although both iron species possess antimicrobial properties, metallic nanoparticles make it more bactericidal than iron oxides. In the presence of dissolved oxygen, metallic nanoparticles can generate a Fenton reaction, producing hydrogen peroxide in addition to ROS [12]. the presence of $\mathrm{Fe}_{2} \mathrm{O}_{3}$ can likely limit the beneficial effect of this modification.

Based on above description, the copper-modified membrane gives a better anti-biofouling effect than the iron and provides less adhesion, thereby proving less important to the roughness effect.

\subsection{Desalination Performance}

Table 2 shows the permeate flux and salt rejection percentage of the modified membranes and the pristine membrane. A slight decrease of permeate flux and rejection percentage on the modified membrane with CuNPs respective to the unmodifed membrane was observed. However, this effect is more detrimental in the presence of FeNPs. This fact can be due to the formation of defects in the polyamide layer by the incorporation of nanoparticles, in concordance with an increase of the 
roughness observed on a modified membrane promoted by the agglomeration of the nanoparticles on the membrane surface; this phenomenon was more strongly observed in the presence of FeNPs. Thus, as a consequence of this modification, the nanoparticles in the active membrane layer may be blocking the preferential flow channel water, reducing the permate capacity [43].

Table 2. Desalination performance of membranes.

\begin{tabular}{ccc}
\hline Membrane & Flux $\left(\mathbf{1} \mathbf{~ m}^{-\mathbf{2}} \mathbf{h}^{\mathbf{- 1}} \mathbf{b a r}^{-\mathbf{1}}\right)$ & Reject $\mathbf{( \% )}$ \\
\hline PA-PSL & $0.61 \pm 0.27^{\mathrm{a}}$ & $94.86 \pm 0.68^{\mathrm{a}}$ \\
PA+0.25Cu-PSL & $0.42 \pm 0.16^{\mathrm{a}}$ & $92.96 \pm 2.79^{\mathrm{a}}$ \\
PA+0.25Fe-PSL & $0.15 \pm 0.03^{\mathrm{b}}$ & $74.36 \pm 4.57^{\mathrm{b}}$ \\
\hline
\end{tabular}

The mean with a different superindex has a difference at $p<0.01$.

\section{Conclusions}

The adding of CuNPs and FeNPs within the PA layer of the TFC-RO membranes during the interfacial polymerization process increased the membrane roughness, thereby affecting the desalination performance, and this effect was more remarkable in the membrane modified with FeNPs. However, a significant bactericidal and anti-adhesion effect on the membrane was achieved. The beneficial anti-biofouling effect was attributed to the influence of reactive oxygen species (ROS) generated in the presence of both NPs, in addition to the high reactivity of $\mathrm{CuNPs}$ for releasing toxic $\mathrm{Cu}^{+2}$ ions. The anti-adhesion capacity was observed in the membranes tested, presenting better results in the $\mathrm{PA}+0.25 \mathrm{Cu}$-PSL membrane with significant differences compared to the PA+0.25Fe-PSL membrane.

Author Contributions: M.A.O: Experimental work related to synthesis and characterization of TFC-RO membrane and discussion of results. Y.Q: Experimental work related to desalination and biological tests and discussion of results. A.L: Experimental work related to synthesis and characterization of nanoparticles. M. M: Experimental work related to synthesis and characterization of nanoparticles. L.A.M: Advice and financing. A.G.G: Advice and discussion of results related to synthesis and characterization of nanoparticles. A.G: Advice and discussion of results related to synthesis, characterization of TFC-RO membrane and their desalination and biological tests, writing of the article and financing.

Funding: This research was funded by Associative Research Program, CONICYT, PIA Project ACM170003, scholarship funding CONACYT (276161), grant number PDCPN 2015-1221 and PROFAPI fund, Project 2019-0135.

Acknowledgments: The authors thank the Associative Research Program of the National Commission of Science and Technology (CONICYT, PIA Project ACM170003). Moreover, we thank Solvay Advanced Polymers for donating the polysulfone Udel P-1700. The authors also thank the Water Quality Laboratory of the Department of Civil Engineering of Universidad de Chile for giving the infrastructure. One of us (M.M.A-O.) would like to thank CONACYT for scholarship funding (276161) and grant number PDCPN 2015-1221, and the Instituto Tecnológico de Sonora through a PROFAPI fund (Project 2019-0135) in Mexico.

Conflicts of Interest: The authors declare no conflict of interest.

\section{References}

1. Gonzalez-Enriquez, R.; Armendariz-Ontiveros, M.M. Evolución de la desalinización del agua: Tecnología y costos, Movimiento Ciudadano por el Agua. Primavera del 2016, 2016, 14-16.

2. IDA. Desalination Yearbook 2017-2018; International Desalination Association: Sao Paulo, Brasil, $2017 ;$ p. 216.

3. Choi, W.; Jeon, S.; Kwon, S.J.; Park, H.; Park, Y.-I.; Nam, S.-E.; Lee, P.S.; Lee, J.S.; Choi, J.; Hong, S.; et al. Thin film composite reverse osmosis membranes prepared via layered interfacial polymerization. J. Membr. Sci. 2017, 527, 121-128. [CrossRef]

4. Fimbres-Weihs, G.A.; Álvarez-Sánchez, J.; Villegas-Álvarez, E. Fouling Modeling and Optimization of Membrane Module Design for Brackish and Seawater Desalination in the Mexican Pacific Coast: Project Description and Progress. Membranes 2017, 135-144. [CrossRef]

5. Bucs, S.S. Biofouling in Reverse and Forward Osmosis Membrane Systems. Ph.D. Thesis, Delft University of Technology, Delft, The Netherlands, 2017. 
6. García, Y.; Quintero, N.; Vicencio, B.; Rodríguez, D.; Ozturk, E.; Mosquera, T.; Corrales, U.; Volkmann, U.G. Influence of $\mathrm{TiO}_{2}$ nanostructures on anti-adhesion and photoinduced bactericidal properties of thin film composite membranes. RSC Adv. 2016, 6, 82941-82948.

7. Pérez-Sicairos, S.; Miranda-Ibarra, S.; Lin-Ho, S.; Álvarez-Sánchez, J.; Pérez-Reyes, J.; Corrales-López, K.; Morales-Cuevas, J. Membranas de nanofiltración, preparadas viá polimerización en interfase, dopadas con nanopartículas de ZnO: Efecto en su desempeño [Nanofiltration membranes, prepared via interface polymerization, doped with $\mathrm{ZnO}$ nanoparticles: Effect on their performance]. Rev. Mex. Ing. Quim. 2016, 15, 961-975.

8. Lee, S.Y.; Kim, H.J.; Patel, R.; Im, S.J.; Kim, J.H.; Min, B.R. Silver nanoparticles immobilized on thin film composite polyamide membrane: Characterization, nanofiltration, antifouling properties. Polym. Adv. Technol. 2007, 18, 562-568. [CrossRef]

9. Tamayo, L.; Azócar, M.; Kogan, M.; Riveros, A.; Páez, M. Copper-polymer nanocomposites: An excellent and cost-effective biocide for use on antibacterial surfaces. Mater. Sci. Eng. C 2016, 69, 1391-1409. [CrossRef]

10. Mulfinger, L.; Solomon, S.; Bahadory, M.; Jeyarajasingam, A.; Rutkowsky, S.; Boritz, C. Synthesis and study of silver nanoparticles. J. Chem. Educ. 2007, 84, 322. [CrossRef]

11. Stefaniuk, M.; Oleszczuk, P.; Ok, Y. Review on nano zerovalent iron (nZVI): From synthesis to environmental applications. Chem. Eng. J. 2016, 287, 618-632. [CrossRef]

12. Armendáriz-Ontiveros, M.M.; García, A.G.; Villalobos, S.d.; Weihs, G.A.F. Biofouling performance of RO membranes coated with Iron NPs on graphene oxide. Desalination 2019, 451, 45-58. [CrossRef]

13. Zhou, L.; Zhuang, W.; Wang, X.; Yu, K.; Yang, S.; Xia, S. Potential effects of loading nano zero valent iron discharged on membrane fouling in an anoxic/oxic membrane bioreactor. Water Res. 2017, 111, 140-146. [CrossRef] [PubMed]

14. Palza, H.; Nuñez, M.; Bastías, R.; Delgado, K. In situ antimicrobial behavior of materials having copper-based additives in a hospital environment. Int. J. Antimicrob. Agents 2018, 51, 912-917. [CrossRef] [PubMed]

15. Cioffi, N.; Torsi, L.; Ditaranto, N.; Tantillo, G.; Ghibelli, L.; Sabbatini, L.; Bleve-Zacheo, T.; D'Alessio, M.; Zambonin, P.; Traversa, E. Copper nanoparticle/polymer composites with antifungal and bacteriostatic properties. Chem. Mater. 2005, 17, 5255-5262. [CrossRef]

16. Aruoja, V.; Dubourguier, H.; Kasemets, K.; Kahru, A. Toxicity of nanoparticles of $\mathrm{CuO}, \mathrm{ZnO}$ and $\mathrm{TiO}_{2}$ to microalgae Pseudokirchneriella subcapitata. Sci. Total Environ. 2009, 407, 1461-1468. [CrossRef] [PubMed]

17. Meghana, S.; Kabra, P.; Chakraborty, S.; Padmavathy, N. Understanding the pathway of antibacterial activity of copper oxide nanoparticles. RSC Adv. 2015, 5, 12293-12299. [CrossRef]

18. Kaweeteerawat, C.; Chang, C.; Roy, K.; Liu, R.; Li, R.; Toso, D.; Fischer, H.; Ivask, A.; Ji, Z.; Zink, J.; et al. Cu nanoparticles have different impacts in Escherichia coli and Lactobacillus brevis than their microsized and ionic analogues. ACS Nano 2015, 9, 7215-7225. [CrossRef] [PubMed]

19. Sarkar, A.; Das, J.; Manna, P.; Sil, P. Nano-copper induces oxidative stress and apoptosis in kidney via both extrinsic and intrinsic pathways. Toxicology 2011, 290, 208-217. [CrossRef] [PubMed]

20. García, A.; Rodríguez, B.; Oztürk, D.; Rosales, M.; Diaz, D.; Mautner, A. Incorporation of CuO nanoparticles into thin-film composite reverse osmosis membranes (TFC-RO) for antibiofouling properties. Polym. Bull. 2017, 75, 2053-2069. [CrossRef]

21. Ben-Sasson, M.; Zodrow, K.R.; Genggeng, Q.; Kang, Y.; Giannelis, E.P.; Elimelech, M. Surface functionalization of thin-film composite membranes with copper nanoparticles for antimicrobial surface properties. Environ. Sci. Technol. 2013, 48, 384-393. [CrossRef]

22. Ben-Sasson, M.; Lu, X.; Nejati, S.; Jaramillo, H.; Elimelech, M. In situ surface functionalization of reverse osmosis membranes with biocidal copper nanoparticles. Desalination 2016, 388, 1-8. [CrossRef]

23. Sarango, L.; Paseta, L.; Navarro, M.; Zornoza, B.; Coronas, J. Controlled deposition of MOFs by dip-coating in thin film nanocomposite membranes for organic solvent nanofiltration. J. Ind. Eng. Chem. 2018, 59, 8-16. [CrossRef]

24. Rodríguez, B.; Oztürk, D.; Rosales, M.; Flores, M.; García, A. Antibiofouling thin-film composite membranes (TFC) by in situ formation of Cu-(m-phenylenediamine) oligomer complex. J. Mater. Sci. 2018, 53, 6325-6338. [CrossRef]

25. Homayoonfal, M.; Mehrnia, M.R.; Shariaty-Niassar, M.; Akbari, A.; Ismail, A.F.; Matsuura, T. A comparison between blending and surface deposition methods for the preparation of iron oxide/polysulfone nanocomposite membranes. Desalination 2014, 354, 125-142. [CrossRef] 
26. Liu, Q.; Yasunami, T.; Kuruda, K.; Okido, M. Preparation of Cu nanoparticles with ascorbic acid by aqueous solution reduction method. Trans. Nonferrous Met. Soc. 2012, 22, 2198-2203. [CrossRef]

27. Baltazar, S.E.; García, A.; Romero, A.H.; Rubio, M.A.; Arancibia-Miranda, N.; Altbir, D. Surface rearrangement of nanoscale zerovalent iron: The role of $\mathrm{pH}$ and its implications in the kinetics of arsenate sorption. Environ. Technol. 2014, 35, 2365-2372. [CrossRef] [PubMed]

28. Arancibia-Miranda, N.; Baltazar, S.E.; García, A.; Romero, A.H.; Rubio, M.A.; Altbir, D. Lead removal by nano-scale zero valent iron: Surface analysis and pH effect. Mater. Res. Bull. 2014, 59, 341-348. [CrossRef]

29. Arancibia-Miranda, N.; Baltazar, S.E.; García, A.; Muñoz-Lira, D.; Sepúlveda, P.; Rubio, M.A.; Altbir, D. Nanoscale zero valent supported by Zeolite and Montmorillonite: Template effect of the removal of lead ion from an aqueous solution. J. Hazard. Mater. 2016, 301, 371-380. [CrossRef]

30. Prabhu, Y.T.; Rao, K.V.; Sai, V.S.; Pavani, T. A facile biosynthesis of copper nanoparticles: A micro-structural and antibacterial activity investigation. J. Saudi Chem. Soc. 2017, 21, 180-185. [CrossRef]

31. Khatami, M.; Heli, H.; Jahani, P.M.; Azizi, H.; Nobre, M.A.L. Copper/copper oxide nanoparticles synthesis using Stachys lavandulifolia and its antibacterial activity. IET Nanobiotechnol. 2017, 11, 709-713. [CrossRef]

32. Marković, D.; Korica, M.; Kostić, M.; Radovanović, Ž.; Šaponjić, Z.; Mitrić, M.; Radetić, M. In situ synthesis of $\mathrm{Cu} / \mathrm{Cu} 2 \mathrm{O}$ nanoparticles on the TEMPO oxidized cotton fabrics. Cellulose 2018, 25, 829-841. [CrossRef]

33. Khan, A.; Rashid, R.; Younas, R.; Chong, A. chemical reduction approach to the synthesis of copper nanoparticles. Int. Nano Lett. 2016, 6, 21-26. [CrossRef]

34. Mdlovu, N.V.; Chiang, C.-L.; Lin, K.-S.; Jeng, R.-C. Recycling copper nanoparticles from printed circuit board waste etchants via a microemulsion process. J. Clean. Prod. 2018, 185, 781-796. [CrossRef]

35. Wang, L.; Hu, C.; Shao, L. The antimicrobial activity of nanoparticles: Present situation and prospects for the future. Int. J. Nanomed. 2017, 12, 1227. [CrossRef]

36. Janko, C.; Zaloga, J.; Pöttler, M.; Dür, S.; Eberbeck, D.; Tietze, R.; Lyer, S.; Alexiou, C. Strategies to optimize the biocompatibility of iron oxide nanoparticles-“SPIONs safe by desing". J. Magn. Magn. Mater. 2017, 431, 281-284. [CrossRef]

37. Kang, G.-d.; Cao, Y.-m. Development of antifouling reverse osmosis membranes for water treatment: A review. Water Res. 2012, 46, 584-600. [CrossRef]

38. Kumar, R.; Ismail, A. Fouling control on microfiltration/ultrafiltration membranes: Effects of morphology, hydrophilicity, and charge. J. Appl. Polym. Sci. 2015, 132, 42042. [CrossRef]

39. Hurwitz, G.; Guillen, G.R.; Hoek, E.M. Probing polyamide membrane surface charge, zeta potential, wettability, and hydrophilicity with contact angle measurements. J. Membr. Sci. 2010, 349, 349-357. [CrossRef]

40. Karlsson, H.; Cronholm, P.; Gustafsson, J.; Möller, L. Copper Oxide Nanoparticles Are Highly Toxic: A Comparison between Metal Oxide Nanoparticles and Carbon Nanotubes. Chem. Res. Toxicol. 2018, 21, 1726-1732. [CrossRef]

41. Palza, H. Antimicrobial polymers with metal nanoparticles. Int. J. Mol. Sci. 2015, 16, 2099-2116. [CrossRef]

42. Bataineh, H.; Pestovsky, O.; Bakac, A. pH-induced mechanistic changeover from hydroxyl radicals to iron (IV) in the Fenton reaction. Chem. Sci. 2012, 3, 1594-1599. [CrossRef]

43. Chae, H.; Lee, J.; Lee, C.; Kim, I.; Park, P. Graphene oxide-embedded thin-film composite reverse osmosis membrane with high flux, anti-biofouling, and chlorine resistance. J. Membr. Sci. 2015, 483, 128-135. [CrossRef]

(C) 2019 by the authors. Licensee MDPI, Basel, Switzerland. This article is an open access article distributed under the terms and conditions of the Creative Commons Attribution (CC BY) license (http://creativecommons.org/licenses/by/4.0/). 